\title{
Meningkatkan Daya Jual Produk Melalui Pemasaran Online Di Masa Pandemi Pada Wirausaha Pelajar Indonesia Kota Bogor
}

\author{
1*Aidil Amin Effendy, ${ }^{2}$ Mahnun Mas'adi, ${ }^{3}$ Ahmad Nurhadi, \\ ${ }^{4}$ Heri Murtiyoko, ${ }^{5}$ Aden Prawiro Sudarso \\ Universitas Pamulang, Tangerang Selatan, Banten, Indonesia \\ Email : "aidi100967@unpam.ac.id
}

Manuskrip: Juni -2021; Ditinjau: Juni -2021; Diterima: Juli -2021;

Online: Juli-2021; Diterbitkan: Juli-2021

\begin{abstract}
ABSTRAK
Sebuah perubahan besar dapat dimulai dengan adanya generasi muda yang unggul dan memiliki jiwa-jiwa tangguh dalam mengembangkan suatu bisnis, seperti komunitas WPI (Wirausaha Pelajar Indonesia) di kota Bogor, diharapkan mampu meningkatkan daya jual produk dan bersaing dengan usaha sejenis lainnya di masa pandemi saat ini. Adapun tujuan dari Pengabdian kepada Masyarakat (PKM) ini adalah untuk memotivasi dan memberikan wawasan terkait strategi dalam meningkatkan daya jual produk melalui pemasaran online di masa pandemi pada WPI (Wirausaha Pelajar Indonesia) Kota Bogor".

Metode yang digunakan pada Pengabdian masyarakat ini berupa penyampaian materi secara verbal melalui media zoom mengenai penelitian yang menunjukkan bahwa media sosial dapat berperan dalam meningkatkan penjualan dan strategi terbaik, efektif dan efisien dalam memanfaatkan media sosial untuk meningkatkan penjualan di masa pandemi, serta membimbing para wirausaha pelajar Indonesia, khususnya wirausaha kota Bogor agar dapat berhasil menerapkannya.

Hasil pengabdian masyarakat oleh dosen-dosen Fakultas Ekonomi Universitas Pamulang dapat membuahkan hasil yang positif terlihat dari antusias dan bersemangat dalam mengikuti pemberian materi, tanya jawab dan diskusi, serta bertambahnya ilmu pengetahuan, wawasan dan bimbingan mengenai penerapan pemasaran melalui media sosial agar dapat meningkatkan penjualan di saat pandemi pada masa ini.
\end{abstract}

\section{Kata Kunci: Wirausaha Pelajar Indonesia, Kota Bogor, Daya Jual, Pemasaran} Online, Masa Pandemi

\section{PENDAHULUAN}

Generasi Muda adalah sebuah generasi unggul sebagai penerus generasi selanjutnya, walaupun saat ini masih di masa pandemi Covid-19, jiwa-jiwa muda yang memiliki bisnis atau UMKM (Usaha Mikro Kecil Menengah) harus terus berinovasi dan mengembangkan bisnisnya agar terus dapat berkembang dan mampu bertahan walaupun di masa pandemi saat ini. Dengan adanya WPI (Wirausaha Pelajar Indonesia) di berbagai cabang yang ada di Indonesia, seperti 
Bogor, Tangerang Selatan dan sebagainya, diharapkan mampu menambah jumlah UMKM di masing-masing kota, khususnya di Kota Bogor dan sekitarnya,

Salah satu upaya mempertahankan usaha di masa pandemi dapat dilakukan melalui strategi pemasaran secara Online seperti pemanfaatan media sosial di kalangan muda-mudi agar membuka peluang terjualnya produk atau jasa yang dipasarkan menjadi lebih luas dan terencana.

Sebagaimana Survey yang dilakukan oleh Badan Pusat Statistik (BPS) dalam Fadly, H. D., \& Sutama, S. (2020), mendata "Pengguna e-commerce yaitu sejumlah 3.504 kepala keluarga (KK) pada 101 daerah di seluruh provinsi yang terdapat di Indonesia. Dari data tersebut dapat diambil kesimpulan bahwa hanya sekitar 15,08\% dari keseluruhan yang menggunakan usaha e-commerce, hal ini berbading terbalik dengan yang tidak menggunakan usaha e-commerce yaitu sebanyak 84.92\%." Seperti diagram terlampir di bawah ini:

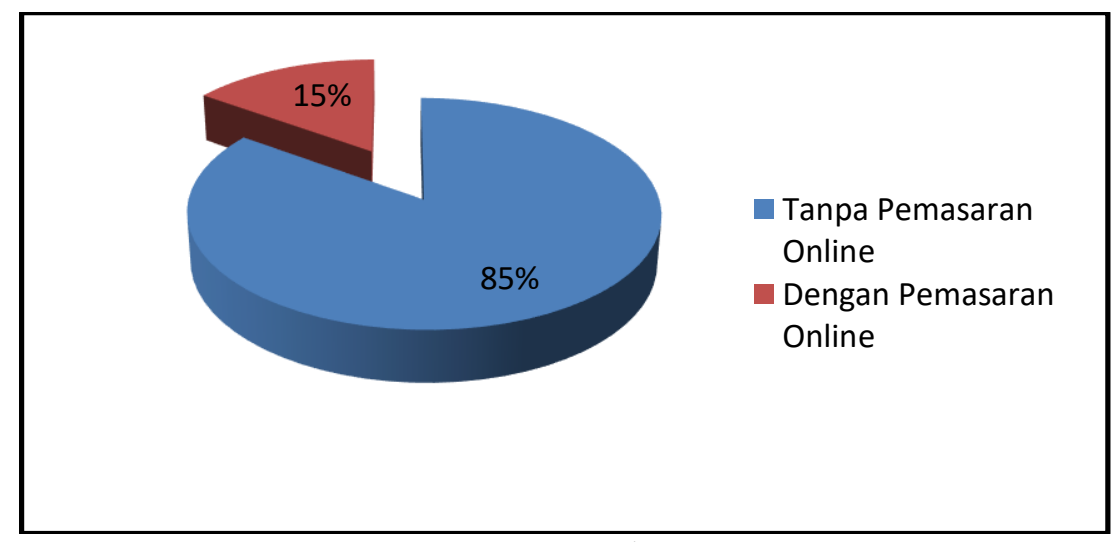

Gambar 1. Presentase Pemasaran Online/e-commerce, Tahun 2020

Dengan melihat data di atas, sebuah usaha yang menjual produk atau jasanya melalui e-commerce di indonesia masih tergolong sangat rendah, hal ini juga mencerminkan wilayah Bogor masih jauh dari harapan usahanya untuk dapat memasarkannya secara Online, para pelaku UMKM lebih memilih menjual produk/jasanya melaluinya toko atau membuka lapak di pinggir jalan, padahal pada era kompetitif ini terutama saat pandemi covid-19 seperti ini, perlu adanya pemasaran melalui Online atau e-commerce yang dapat meningkatkan daya jual produk dan bersaing dengan usaha sejenis lainnya.

Sebagaimana hasil penelitian yang dilakukan oleh R. Rahayu, \& J. Day, (2015) "Karakteristik UMKM di Indonesia masih sangat sedikit untuk mengembangkan pemasaran digital yang bersifat berjejaring dan menggunakan teknologi yang canggih. UMKM yang masih menggunakan situs statis sebesar $32,5 \%$, situs interaktif $25 \%$ dan belum terlibat secara digital memiliki persentase 7,2\% UMKM."

Hal ini diperkuat dalam sebuah riset oleh A. Budiyanto, \& A.A. Effendy, (2020), diantara hambatan perkembangan UMKM ialah "Terbatasnya sarana dan prasarana usaha terutama berhubungan dengan alat-alat teknologi. Kebanyakan 
UMKM menggunakan teknologi yang masih sederhana sehingga sulit untuk bersaing secara kualitas dan kuantitas."

Karena saat ini pada masa era digital, maka sebuah solusi dalam mengembangkan usaha yaitu dengan pemasaran melalui digital atau promosi Online, hal ini sebagaimana riset yang dilakukan oleh Effendy, A. A., \& Sunarsi, D. (2020). "Promosi sangat efektif dilakukan melalui media Online terutama lebih efektif dilakukan promosinya melalui media sosial dibandingkan promosi melalui media elektronik, dan media cetak."

Sebagaimana juga riset yang dilakukan oleh Anugrah, R. J. (2020), menurutnya, "Dengan kecenderungan masyarakat yang lebih memilih menghabiskan waktu dengan menggeluti media sosial, perusahaan akan dengan mudah mencapai target yang mereka tentukan."

Oleh karena itu, WPI (Wirausaha Pelajar Indonesia) sebagai wadah para remaja yang berwirausaha baik dari kalangan pelajar maupun mahasiswa, khususnya Kota Bogor, perlu mempelajari secara mendalam mengenai keilmuan berbisnis, agar usaha atau bisnis yang dijalankan dapat mampu bertahan dan berkembang di saat pandemi seperti saat ini. Namun para remaja yang tergabung dalam sebuah wadah atau organisasi seperti WPI (Wirausaha Pelajar Indonesia) perlu juga didukung karena baik organisasi ataupun "Sebuah lembaga, semestinya perlu didukung oleh semua eleman masyarakat, baik guru, orangtua, masyarakat sekitar dan termasuk dosen-dosen diharapkan dapat mengabdi dan berperan serta dalam membentuk untuk mewujudkannya. (Effendy, A. A., et. al (2020).

Dalam pengabdian kepada masyarakat (PKM) yang dilakukan oleh dosendosen UNPAM khsusnya dosen Manajemen Fakultas Ekonomi, merupakan salah satu upaya dalam berpartisipasi dan menjalankan peran untuk membekali dan memberikan ilmu pengetahuan, keterampilan dan karakter dalam mendidik para remaja yang berwirausaha yang tergabung dalam WPI (Wirausaha Pelajar Indonesia) dengan tema, "Meningkatkan Daya Jual Produk melalui Pemasaran Online di Masa Pandemi pada WPI (Wirausaha Pelajar Indonesia) Kota Bogor".

\section{METODE}

Metode Pelaksanaan Pengabdian Masyarakat ini di antaranya : Tahap Pertama yaitu Pemberian materi PKM kepada WPI (Wirausaha Pelajar Indonesia) Kota Bogor dan peserta PKM dari kota lainnya, di antara materi yang disampaikan Tim PKM Dosen yaitu mengenai penelitian yang menunjukkan bahwa media sosial dapat berperan dalam meningkatkan penjualan dan strategi dalam "Meningkatkan Daya Jual Produk melalui Pemasaran Online di Masa Pandemi”.

Dalam Effendy, A. A., etc. (2020), menurut Prof. Dr. S. Nasution (2015:26) berpendapat mengenai "Ciri-ciri Belajar yang ditinjau berdasarkan sumber yaitu diantaranya memanfaatkan sepenuhnya segala sumber informasi sebagai sumber bagi pelajaran termasuk alat-alat audio-visual dan memberi kesempatan untuk merencanakan kegiatan belajar dengan mempertimbangkan sumber-sumber yang tersedia." Dalam pemberian materi PKM oleh dosen-dosen menggunakan alat 
bantu berupa aplikasi zoom dikarenakan masih dalam masa pandemi Covid 19, seperti gambar di bawah ini:

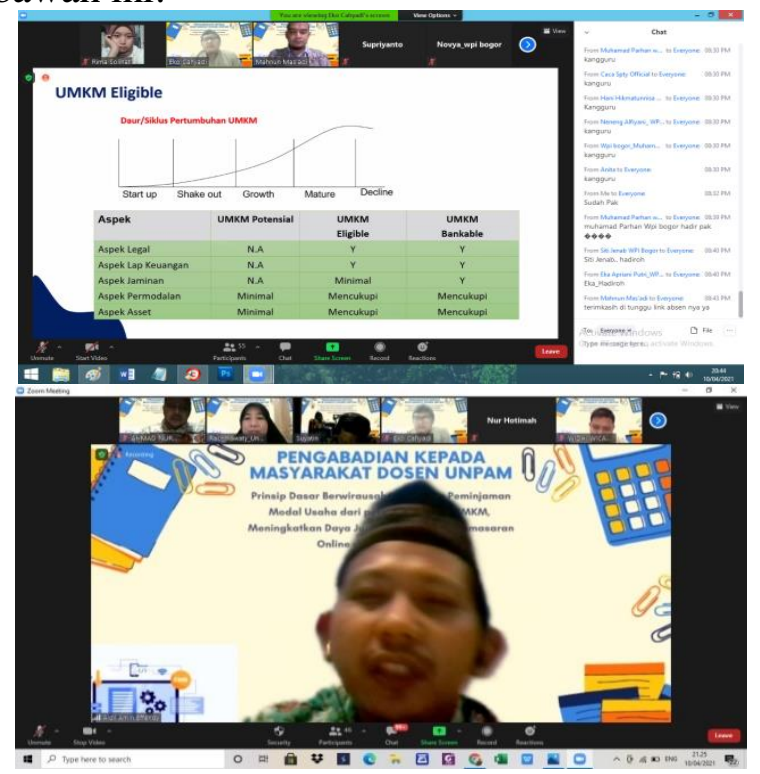

Gambar 2. Tim PKM Dosen Universitas Pamulang Sedang Memberikan Materi

Selain pemberian materi PKM oleh tim PKM Dosen, terdapat juga sambutan dari Mitra PKM yaitu Bapak H. Hasbulloh, S.E., MA.Ek. sebagai Founder WPI Kota Bogor yang memberikan motivasi kepada wirausaha muda agar dapat berjuang mengembangkan usahanya. Tim PKM Dosen juga mengadakan ice breaking sebelum pemberian materi PKM agar peserta lebih fokus dalam mengikuti penyuluhan yang dilakukan dosen-dosen Fakultas Ekonomi Universitas Pamulang, seperti pada gambar berikut:
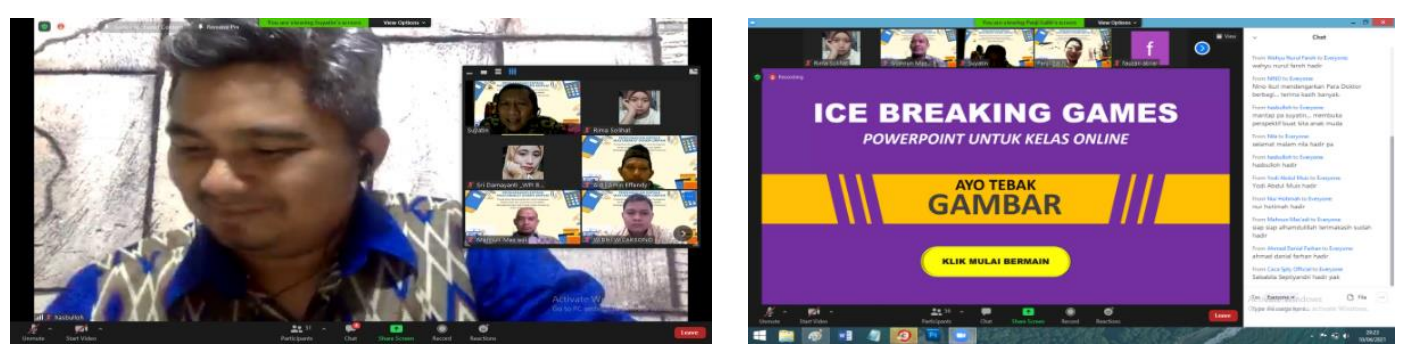

Gambar 3. Ice Breaking oleh Tim PKM

Tahap kedua yaitu : Diskusi dan Tanya Jawab mengenai strategi terbaik dalam meningkatkan penjualan melalui Pemasaran Online di Masa Pandemi. Salah satu solusi terbaik yang diberikan kepada mitra bimbingan yaitu dengan melakukan pemasaran melalui media sosial yang saat ini dapat dikatakan lebih efektif dan efisien.

Kegiatan diadakan pada WPI (Wirausaha Pelajar Indonesia) Kota Bogor selama 3 hari yaitu pada tanggal 9-11 April 2021 melalui Video Conference dengan aplikasi Zoom. 


\section{HASIL DAN PEMBAHASAN}

Hasil dari pemberian materi mengenai cara meningkatkan daya jual produk melalui Pemasaran Online di Masa Pandemi oleh dosen Manajemen Universitas Pamulang dan simulasi cara menjualnya melalui media sosial dan bimbingan agar peserta PKM dapat berhasil pada penerapanya.

Setelah Tim PKM Dosen menyampaikan materi PKM, dilanjutkan dengan sesi tanya jawab kepada peserta agar peserta dapat lebih memahami dan menerapkan keilmuan materi PKM ini dalam usahnya masing-masing. Hasil pengabdian masyarakat yang diperoleh adalah bertambahnya keilmuan WPI (Wirausaha Pelajar Indonesia) Kota Bogor dalam menggunakan media online seperti media sosial dalam meningkatkan penjualan suatu produk atau jasa.
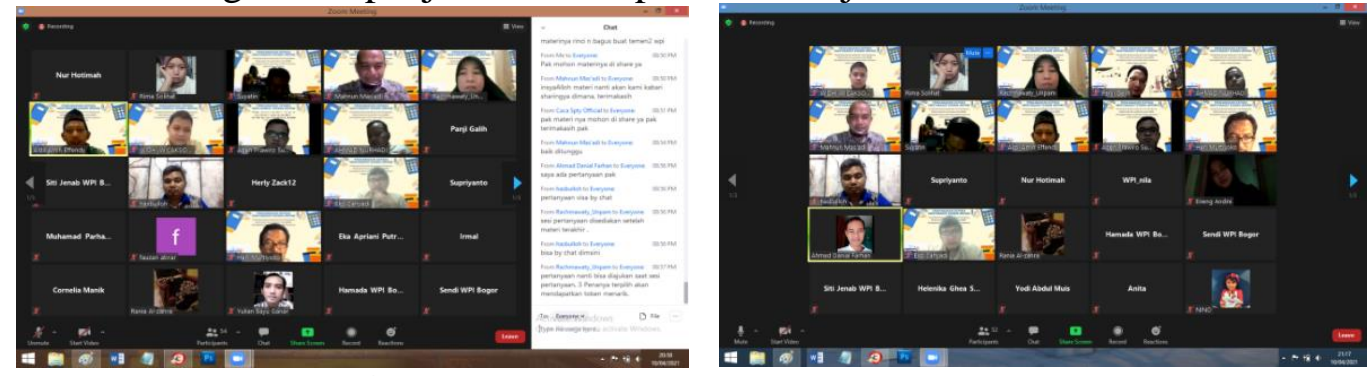

Gambar 4. Sesi Diskusi dan Tanya Jawab bersama WPI Kota Bogor

Adapun gambar di atas yaitu diskusi dan tanya jawab antara peserta kepada Tim PKM, kemudian Tim PKM yang merupakan dosen-dosen Unpam menanggapi dan menjawab pertanyaan yang diajukan oleh para peserta dan memberikan hadiah kepada para peserta yang bertanya dan berhasil menjawab pertanyaan dari Tim PKM Dosen.

\section{KESIMPULAN}

Hasil dari Pelaksanaan kegiatan PKM oleh dosen-dosen Fakultas Ekonomi Universitas Pamulang dapat membuahkan hasil yang positif terlihat dari antusias dan bersemangat dalam mengikuti pemberian materi, tanya jawab dan kuis.

Saran kami bagi WPI (Wirausaha Pelajar Indonesia) Kota Bogor untuk dapat secara konsisten menerapkan pemasaran melalui media sosial agar dapat meningkatkan penjualan di saat pandemi pada masa ini.

Kami berharap kegiatan pengabdian kepada masyarakat di masa yang akan datang dapat lebih terprogram dan terlaksana dengan baik. Semoga kegiatan pengabdian masyarakat ini dapat bermanfaat bagi masyarakat, khususnya WPI (Wirausaha Pelajar Indonesia) Kota Bogor.

\section{DAFTAR PUSTAKA}

Anugrah, R. J. (2020). "Efektifitas Penerapan Strategi Online Marketing oleh UMKM dalam Masa Pembatasan Sosial Berskala Besar (PSBB) Corona Viruses Disease 2019 (Covid-19)." MANOVA (Jurnal Manajemen dan Inovasi), 2(2). 
Budiyanto, A., \& Effendy, A. A. (2020). Analisa Kebijakan Pemerintah Kota Tangerang Selatan terhadap Pemberdayaan Koperasi dan UMKM dan Dampaknya terhadap Pemerataan Kesejahteraan Masyarakat. Jurnal Mandiri: Ilmu Pengetahuan, Seni, Dan Teknologi, 4(1), 80-93.

Effendy, A. A., Budiyanto, A., Nurhadi, A., Murtiyoko, H., \& Mas'adi, M. (2020). "Implementasi Kewirausahaan dan Koperasi di Sekolah pada SMK Mulia Buana, Parung Panjang-Kab. Bogor.” DEDIKASI PKM, 1(2), 105-110.

Effendy, A. A., Mas'adi, M., Wicaksono, W., Nurhadi, A., \& Murtiyoko, H. (2020). "Mewujudkan Generasi Muda Yang Unggul Di Era Globalisasi Dengan Berbekal Ilmu Wirausaha Yang Kreatif, Inovatif Dan Diferensiatif Pada Remaja Masjid Al Hikmah Reni Jaya Pamulang Tangerang Selatan.” Jurnal Pengabdian Dharma Laksana, 3(1), 8-15.

Effendy, A. A., Sudarso, A. P., Nurhadi, A., Arifianto, C. F., \& Kartono, K. (2020). "Peningkatan Profesionalisme Guru Dan Pengembangan SDM Dalam Menghadapi Era Revolusi Industri 4.0 Pada Guru Smk Mulia Buana Parung Panjang Bogor." Abdi Laksana, 1(2).

Effendy, A. A., \& Sunarsi, D. (2020). Persepsi Mahasiswa Terhadap Kemampuan Dalam Mendirikan UMKM Dan Efektivitas Promosi Melalui Online Di Kota Tangerang Selatan. Jurnal Ilmiah MEA (Manajemen, Ekonomi, \& Akuntansi), 4(3), 702-714.

Fadly, H. D., \& Sutama, S. (2020). "Membangun Pemasaran Online Dan Digital Branding Ditengah Pandemi Covid-19." Jurnal Ecoment Global: Kajian Bisnis dan Manajemen, 5(2), 213-222.

Mas'adi, M., Effendy, A. A., Nurhadi, A., Wicaksono, W., \& Murtiyoko, H. (2021). Berwirausaha Dengan Semangat Kolaborasi Bersama Kurir Online Pada Pelaku UMKM Di Wilayah Reni Jaya Pamulang Barat. Jurnal Pengabdian Dharma Laksana, 3(2), 173-178.

Nasution, Prof. Dr. S., 2015. "Berbagai Pendekatan dalam Proses Belajar dan Mengajar”, PT Bumi Aksara, Jakarta

Rahayu, R., \& Day, J. (2015). Determinant Factors of E-commerce Adoption by SMEs in Developing Country: Evidence from Indonesia. Procedia-Social and Behavioral Sciences, 195, 142-150.

Suhendar, D., \& Suhardi, D. (2018). "Optimalisasi Pengelolaan Usaha Kecil Menengah (UKM) Kerupuk Dorokdok Desa Cibingbin Kecamatan Cibingbin, Kabupaten Kuningan. Empowerment." Jurnal Pengabdian Masyarakat, 1(02).

Sunarsi, D., \& Asmalah, L. (2018). "Pelatihan Manajemen Pengembangan Diri Bagi Penerima Beasiswa RZIS UGM Dan Dompet Shalahuddin Jogjakarta". Jurnal Pengabdian Dharma Laksana, 1(1). 